\title{
Semi-automatic Scoring Tool for Comet Assay
}

\author{
E. Kiziltan ${ }^{1 *}$, E. Yurtcu ${ }^{2}$ \\ ${ }^{1}$ Baskent University, Faculty of Medicine, Department of Physiology, Ankara, Turkey \\ erhankiziltan@gmail.com \\ ${ }^{2}$ Baskent University, Faculty of Medicine, Department of Physiology, Ankara, Turkey \\ erkanyurtcu@gmail.com \\ *Corresponding author
}

\begin{abstract}
Comet assay or single-cell gel electrophoresis is a widely used method for DNA damage assessment. The results of the method can be scored under microscopic examination either with the naked eye or by automated systems. In this study, we present a semi-automatic comet assay analysis tool that was developed in our laboratory. The results obtained with our tool were compared with that of fully automatic shareware software. The preliminary results suggest that the presented semi-automatic software is an accurate and reliable tool for evaluation of comet assay.
\end{abstract}

Keywords: DNA damage, comet assay, tail moment, image analysis, segmentation.

\section{Introduction}

Cellular DNA damage can occur after intrinsic and extrinsic factors such as high-energy radiation, alkylating agents, reactive oxygen species and DNA replication errors (Nowsheen et al. 2012). This process is associated with many diseases. In the last three decades, new methodologies that are able to evaluate DNA damage have been developed. The comet assay or single-cell gel electrophoresis (SCGE) is one of the widely used standard methods for assessing DNA damage. This assay is fundamental for genotoxicity testing, biomonitoring and ecogenotoxicology. The principle of the method is simple to use, sensitive and reliable (CortésGutiérrez et al. 2011).

Comet assay image scoring is made microscopically, with the naked eye or using image analysis software. Scoring with the naked eye is very easy; however, it is subjective, depends on researcher's experience, and has limitations for evaluating all the parameters that researchers may need. These disadvantages create the need for developing a standard method. Image analysis software programs evaluate various parameters for individual cells objectively and irrespective of the user's experience and also prevent wasting time (Collins 2004).

Broad range parameter scale can be measured by either manual or fully automated image analysis algorithms. The most common parameters measured by image analysis software programs are Comet Area, Head DNA\%, Comet Length, Tail Length, Head Area, Tail DNA\%, Head DNA Content, Tail Moment and Olive Moment (see Table 1) (Gyori et al. 2014, Olive et 
al. 2006). Several commercial and freeware software programs are available on the market. They all measure these common parameters by using different approaches and programming algorithms, and intend to solve particular problems in the field. Although the automated systems have many advantages, the commercial software programs are expensive and the shareware (such as OpenComet (Gyori et al. 2014)) have some restrictions.

In this study, we present the preliminary validation results of a semi-automatic comet assay analysis tool that was developed in our laboratory. The tool incorporates both manual and automatic features and provide user with reshaping options for comet and head segmentations. We aimed to obtain reliable and accurate measurement results, the same as the automated systems get, and in the future we intend to make this tool freely available to researchers.

\section{Materials and Methods}

\subsection{Comet Assay and Image Acquisition}

Human hepatocellular carcinoma cells, HepG2 (HB 8065, ATCC, USA), were cultured in standard cell culture conditions. Genotoxic damage was induced by doxorubicin and comet assay was performed. Briefly, cells suspension was mixed with low melting point agarose (LMPA; Sigma-Aldrich) and spread on to the slides coated with normal melting point agarose (NMPA; Sigma-Aldrich). After solidification of agarose, the third layer of LMPA was added on to the slides. For denaturing cellular membranes, slides were incubated in lysis solution at $4^{\circ} \mathrm{C}$ (in dark environment) for $2 \mathrm{~h}$. Slides were incubated in electrophoresis buffer for $20 \mathrm{~min}$ in dark environment and electrophoresis was performed. After neutralization, the slides were stained with ethidium bromide and photographed under the fluorescence microscope (Nikon, Eclipse 600, Japan) (Yurtcu et al. 2014).

\subsection{Image Analysis Software}

The image analysis software (tool) was developed in-house and written in Borland Delphi version 6.0 programming language, running under Microsoft Windows 98 (Microsoft Corporation, Seattle, WA) and higher operating systems. Operational screen design and variables were simply organized so that the single page graphical user interface provides users with a friendly environment. The possible upgrades and expansions for future needs were also taken into account in programming algorithm. The software accepts static image of comet assay slide in jpeg format, which has already been acquired by the software of the microscope.

The software allows a user to perform metric calibration, adjust color threshold set value and angular/radial resolutions before starting image analysis. The user then visually evaluates each comet-like object and assesses whether it is a real comet or not. The centers of the head and the tail of the real comets are selected by mouse clicks. The entire comet and comet head segmentations are performed automatically by using the radial mapping algorithm. Typical user interface is given in Fig. 1. 


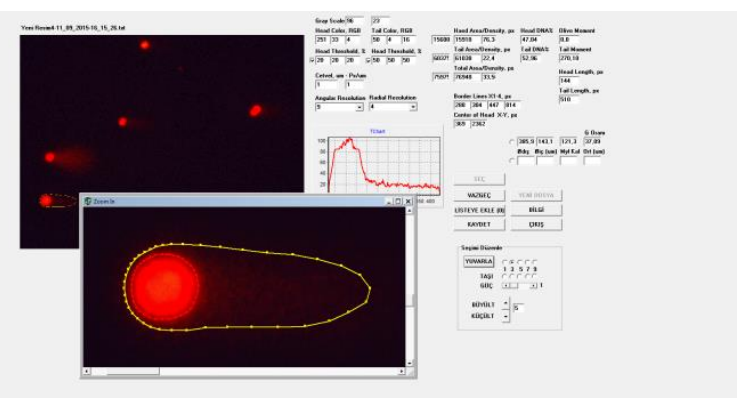

Fig.1. Single page, user-friendly graphical user interface. The active window in front of the screen displays automatically segmented comet/head by 40 points ( 9 degree angular resolution).

The algorithm uses the predefined threshold set value and angular/radial resolutions to assess the borders of comet/head. The angular resolution for these circular/elliptic structures can be adjusted to $1,3,5$ or 9 degrees so that the comet/head segmentations can be represented by $360,120,72,40$ points in a clockwise direction. The radial resolution, from the center to peripheral direction, can be adjusted by selecting the appropriate number of pixels. The optimal resolution for each comet may be related to the metric size of the comet and the pixel size of image acquisition.

If the user is not satisfied with the automatic segmentations displayed in a new window (see Fig. 1), the software allows the user to reshape the comet and the head manually by using a reshaping tool. The reshaping tool allows moving the points, smoothing, shrinkage and enlargement of elliptic object etc. Predefined scoring parameters are computed in accordance with the current segmentations (Fig. 2) in pixel based and are displayed on the screen. After this step, the software is ready for the next comet selection. When the analyses of all comet-like objects are completed, each comet is enumerated and the measured parameters are saved automatically in a spreadsheet file for further analysis. The final image with comet segmentations is also saved into the working directory.

The commonly used parameters for the assessment of DNA damage are given with a short description in Table 1. Three of them are accepted to be particularly good indicators for DNA damage: Tail DNA\%, Tail Moment and Olive Moment (Gyori et al. 2014, Olive et al. 2006). The presented software computes and outputs most of the parameters given in the table.

\begin{tabular}{ll}
\hline \hline Parameter & Description \\
\hline Comet Length / Area & Length and area of the comet in pixel \\
Comet DNA Content & Sum of color intensity inside the comet \\
Comet Average Intensity & Comet DNA content divided by comet area \\
Head Length / Area & Length and area of the head in pixel \\
Head DNA Content & Sum of color intensity inside the head \\
Head Average Intensity & Head DNA content divided by head area \\
Tail Length / Area & Length and area of the tail in pixel \\
Tail DNA Content & Sum of color intensity inside the tail \\
Tail Average Intensity & Tail DNA content divided by tail area \\
\hline
\end{tabular}

Table 1. The commonly used comet parameters 
In this preliminary study, for the validation of our results, we used Tail Moment (as it is most commonly used parameter (Liao et al. 2009). Tail Moment is calculated as tail length times tail DNA content as a percentage of comet DNA content. The computations were made based on the lines and the contours given in Fig. 2. DNA content is directly proportional to the fluorescence intensity of the interested area. The area and the length of the tail used in the calculations are obtained by subtracting the related values of head from comet.

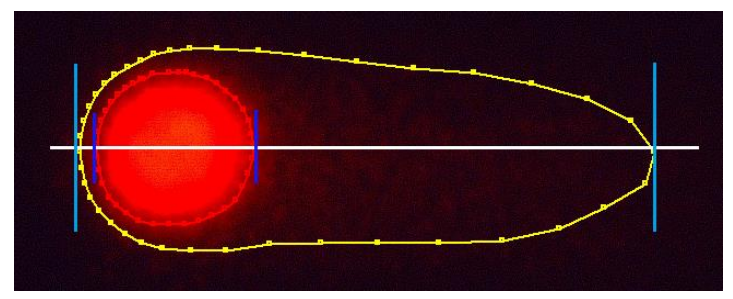

Fig. 2. Critical lines and distances used in scoring a comet. Red spherical line: borders comet head. Yellow elliptic line: borders comet. Distance between light blue lines: comet length.

Distance between dark blue lines: head length

\subsection{Validation of Segmentations and Scoring}

The results of our semi-automatic comet assay tool were compared with the fully automatic shareware software OpenComet. The interested parameters were measured on 20 comets by the two software programs. First, we validated our measurements and computations by comparing the results with that of OpenComet. For one-to-one comparison of identical comet segments, we overlapped the borders of our software on the output image of OpenComet (Fig. 3). Then, a similar segment was obtained manually by using the reshaping options of our software. The interested parameters for the similar comet segmentations were computed by the two software programs and compared. To evaluate scoring performance for DNA damage, Tail Moments of the comets, computed independently by the two software programs were compared.

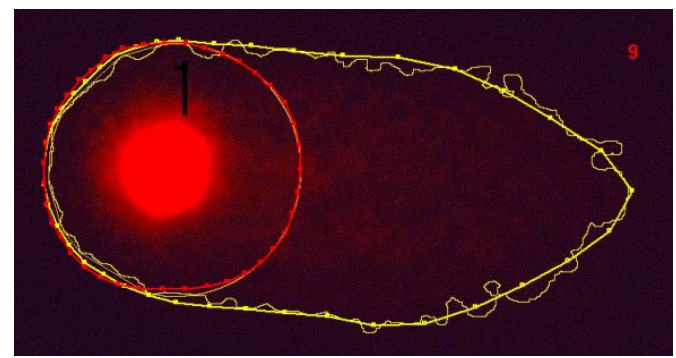

Fig. 3. Comet segmentations made by the two methods for one-to- one comparison. While the red and the yellow lines with square data markers belong to semi-automatic method, the curly yellow-brown lines were drawn by fully automatic OpenComet software.

\subsection{Statistical Analysis}

The results of semi-automatic and fully automatic software were compared by means of Tail Moment calculations. The statistical software package of SPSS (Version 17, Chicago IL) was used for comparison. The results were analyzed statistically by paired sample t-test. Statistically, $\mathrm{p}<.05$ was considered to indicate significance. 


\section{Results}

Pixel based computations of all parameters for the identical comet segmentations were found to be almost the same. Therefore, measurement and computational algorithms were validated for the two software programs. The mean difference between the Tail Moments computed by the two software programs was $46.9 \pm 44.0$ arbitrary units (mean \pm std. dev). While this difference between the software programs was statistically significant $(\mathrm{t}=4.769, \mathrm{p}<0.01)$, the correlation between the data sets was strong enough (correlation coefficient $=0.851, \mathrm{p}<0.01$ ). The whole data sets for Tail Moments were given in Fig. 4, graphically.

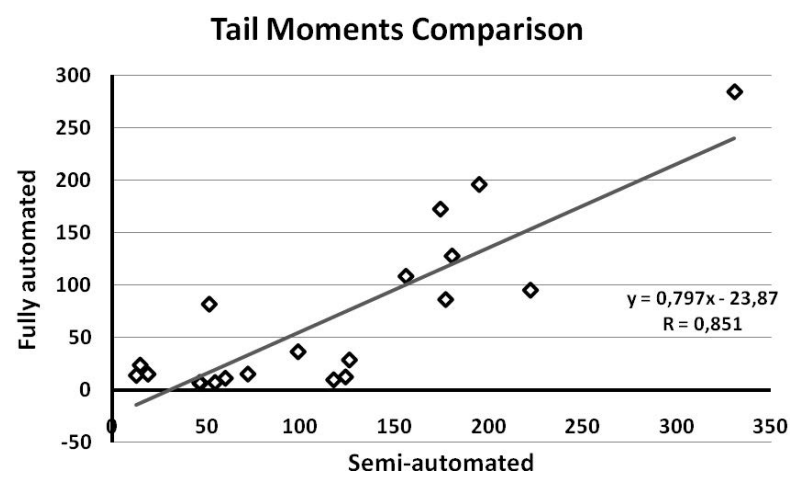

Fig. 4. The parametercomparison of the Tail Moments computed for 20 comets by the two software (fully automated and semi-automated). The correlation coefficient and the regression curve are given on the graph $(\mathrm{p}<0.01, \mathrm{n}=20)$.

\section{Discussion}

In this study we aimed to determine the performance of our software and to validate our results. The results showed that the pixel based measurements and computations of our tool were identical to OpenComet (data not shown). Tail Moment was the preferred parameter for the performance evaluation. There was a strong correlation between the data sets obtained from both software programs. This means that fully automatic and semi-automatic systems show similar, linear responses for the Tail Moment, which is accepted as an important measure for DNA migration.

High throughput automated comet assay analysis systems usually apply some normalization processes to the acquired image before the scoring algorithms are started. Image normalization includes black/white level corrections and corrections to compensate for irregular illuminated areas. We did not use such corrections in our semi-automatic analysis software, since the centers of individual comets are selected by the user and the contours of comets may be corrected manually following the automatic segmentation process. Manual correction is performed through the reshaping options of the software. Therefore, the presented software has both manual and automated systems' features.

There are several limitations of this preliminary study such as small data size for statistical analysis, the numbers of analyzed parameters, the performance of comet segmentation algorithm, etc. Inter- and intra-user invariabilities in measured parameters are guaranteed if all the comets in a set of images are analyzed with the same analysis options. We think that a lot has to be done to reach comparable scorings between the platforms. 
The software we present may be suggested as a reliable and accurate tool for assessing DNA damage. At this stage of the study, we intend to make the software freely available to interested readers and to open feedback channels for further development.

Acknowledgements This study has been presented at the 15th IEEE International Conference on Bioinformatics and Bioengineering, Belgrade, Serbia, on November 02-04, 2015.

Извод

\section{Полуаутоматски алат за мерење код комет теста}

\section{Erhan Kiziltan $^{1 *}$, Erkan Yurtcu $^{2}$}

1 Baskent University, Faculty of Medicine, Department of Physiology, Ankara, Turkey erhankiziltan@gmail.com

2 Baskent University, Faculty of Medicine, Department of Physiology, Ankara, Turkey erkanyurtcu@gmail.com

*главни аутор

\section{Резиме}

Комет тест или једноћелијска гел електрофореза је широко распрострањена метода за процену оштећења ДНК. Резултати методе могу се израчунати микроскопским испитивањем голим оком или аутоматским системима. У овом раду, представићемо полуаутоматски алат за анализу комет теста који је развијен у нашој лабораторији. Резултати добијени нашим алатом поређени су са у потпуности аутоматским софтвером са ограниченом употребом. Прелиминарни резулати указују да је представљени полуаутоматски софтвер тачан и поуздан алат за евалуацију комет теста.

Кључне речи: ДНК оштећење, комет тест, момент репа, анализа снимка, сегментација

\section{References}

Collins AR (2004). The comet assay for DNA damage and repair: principles, applications, and limitations, Mol Biotechnol, 26(3), 249-261.

Cortés-Gutiérrez EI, Dávila-Rodríguez MI, Fernández JL, López-Fernández C, Gosálbez A, Gosálvez J (2011). New application of the comet assay: chromosome-comet assay, J Histochem Cytochem, 59(7), 655-660. Available: http://doi:10.1369/0022155411410884

Gyori BM, Venkatachalam G, Thiagarajan PS, Hsu D, and Clement MV (2014). OpenComet: An automated tool for comet assay image analysis, Redox Biology, 2, 457-465. Available: http://doi:10.1016/j.redox.2013.12.020

Liao W, McNutt MA, Zhu WG (2009). The comet assay: a sensitive method for detecting DNA damage in individual cells, Methods, 48(1), 46-53. Available: http://doi:10.1016/j.ymeth.2009.02.016

Nowsheen S, Yang ES (2012). The Intersection Between DNA Damage Response and Cell Death Pathways, Experimental Oncology, 34(3), 243-254. 
Olive PL, and Banáth JP (2006). The comet assay: a method to measure DNA damage in individual cells, Nature Protocols, 1, 1. Available: http://doi:10.1038/nprot.2006.5

Yurtcu E, Iseri Ö, Sahin F (2014). Genotoxic and cytotoxic effects of doxorubicin and silymarin on human hepatocellular carcinoma cells, Hum ExpToxicol, 33(12), 1269-76. Available: http://doi:10.1177/0960327114529453 